\title{
Synthesis of the $\mathrm{N}$-(tert-butyloxycarbonyl)- 0-triisopropylsilyl-d-pyrrolosamine glycal of lomaiviticins A and B via epimerization of $l-$ Threonine
}

\section{Citation}

Morris, William J., and Matthew D. Shair. 2010. “Synthesis of the N-(tert-Butyloxycarbonyl)0 -Triisopropylsilyl-d-Pyrrolosamine Glycal of Lomaiviticins A and B via Epimerization of LThreonine." Tetrahedron Letters 51 (33) (August): 4310-4312. doi:10.1016/j.tetlet.2010.06.028.

\section{Published Version}

doi:10.1016/j.tetlet.2010.06.028

\section{Permanent link}

http://nrs.harvard.edu/urn-3:HUL.InstRepos:33464224

\section{Terms of Use}

This article was downloaded from Harvard University's DASH repository, and is made available under the terms and conditions applicable to Open Access Policy Articles, as set forth at http:// nrs.harvard.edu/urn-3:HUL.InstRepos:dash.current.terms-of-use\#OAP

\section{Share Your Story}

The Harvard community has made this article openly available.

Please share how this access benefits you. Submit a story.

\section{Accessibility}




\title{
Synthesis of the $\mathrm{N}$-(tert-butyloxycarbonyl)-O-triisopropylsilyl-D- pyrrolosamine Glycal of Lomaiviticin A \& B via Epimerization of L-Threonine
}

\author{
William J. Morris and Matthew D. Shair ${ }^{\star}$ \\ Department of Chemistry and Chemical Biology, Harvard University, 12 Oxford Street Cambridge, \\ MA 02138
}

\section{Abstract}

An efficient synthesis of the $N$-(tert-butyloxycarbonyl)- $O$-triisopropylsilyl-D-pyrrolosamine glycal of lomaiviticin A (1) and lomaiviticin B (2) is described. The synthesis is highlighted by the epimerization of the L-threonine-derived oxazolidine $\mathbf{1 0}$ to oxazolidine 11. This key epimerization reaction, which serves to establish the correct relative configuration of the carbohydrate unit, was made possible only after conformational analysis indicated that substituted oxazolidines may adopt conformations that preclude enolization.

In 2001, He and coworkers reported the isolation and characterization of lomaiviticin A (1) and lomaiviticin B (2) (Figure 1).1 These molecules are potent growth inhibitors against 24 cultured human cancer cell lines $\left(\mathrm{GI}_{50}=0.01-98 \mathrm{ng} / \mathrm{ml}\right)$. The cytotoxicity patterns of $\mathbf{1}$ and 2 in a 24 cell line panel of human cancer cells are unique, suggesting that they have novel mechanisms of action.

In addition to their potent activity in cells, $\mathbf{1}$ and $\mathbf{2}$ are unprecedented $\mathrm{C} 2$-symmetric structures. They share identical core structures, but lomaiviticin A is glycosylated at $\mathrm{C} 3$ and C3' while the $\mathrm{C} 3$ and $\mathrm{C} 3$ ' carbinols of lomaiviticin $\mathrm{B}$ are engaged as ketals with $\mathrm{C} 1$ and $\mathrm{C} 1$ '. The $\mathrm{C} 4$ and $\mathrm{C} 4$ 'carbinols of $\mathbf{1}$ and $\mathbf{2}$ are glycosylated with rare $\mathrm{N}, \mathrm{N}$-dimethylpyrrolosamine carbohydrates. Both $\mathbf{1}$ and $\mathbf{2}$ possess a diazobenzofluorene ring system that evokes comparisons to the kinamycin family of natural products. 2 Progress towards the synthesis of $\mathbf{1}$ and $\mathbf{2}$ has been reported,3 including our approach to the central ring system of lomaiviticin A using a stereoselective oxidative enolate dimerization of a 7-oxanorbornanone. 4

Recently, the synthesis of the $\mathrm{N}, \mathrm{N}$-dimethylpyrrolosamine carbohydrate found in both $\mathbf{1}$ and 2 has been addressed by our group5 as well as Herzon and coworkers. 6 In this communication, we describe an alternative synthesis of the $N, N$-dimethylpyrrolosamine sugar that utilizes an interesting and useful epimerization reaction.

Our initial synthesis plan is outlined in Scheme 1. We targeted a suitably protected glycal that could ultimately be converted to a glycosyl donor. The retrosynthetic analysis began from glycal $\mathbf{3}$ which would be obtained via cycloisomerization of $\mathbf{4}$. Alkynol $\mathbf{4}$ would be

(C) 2010 Elsevier Ltd. All rights reserved.

*Corresponding author. Tel.: 1-617-495-5008; fax: 1-617-496-4591-; shair@ chemistry.harvard.edu.

Publisher's Disclaimer: This is a PDF file of an unedited manuscript that has been accepted for publication. As a service to our customers we are providing this early version of the manuscript. The manuscript will undergo copyediting, typesetting, and review of the resulting proof before it is published in its final citable form. Please note that during the production process errors may be discovered which could affect the content, and all legal disclaimers that apply to the journal pertain. 
accessed from methyl ester $\mathbf{5}$, which could be derived from the amino acid D-allo-threonine (6).

An initial challenge to this synthesis plan was the limited commercial availability of D-allothreonine 6.7 Given the potential utility of this amino acid in organic synthesis, it was not surprising that several methods are available for its preparation. 8 Despite the availability of these methods, we were interested in devising a more efficient strategy to access this important amino acid. Specifically, we sought to develop a strategy where L-threonine 7 could be epimerized at the amino strereocenter to provide the desired D-allo-threonine configuration since $\mathbf{7}$ is readily available (Scheme 2).

Our revised plan was to start the synthesis route outlined in Scheme 1 with L-threonine (7) instead of its more expensive diastereomer $\mathbf{6}$. We surmised that the enolate of the Lthreonine-derived oxazolidine $\mathbf{8}$ would be protonated from the $s i$-face, providing the desired configuration at the amino streocenter. This epimerization strategy offered 2 distinct advantages over the approaches previously reported in the literature. First, our synthesis would begin from 7 , a cheap and readily available starting material. Second, this strategy provides an alternative to undertaking a separate synthesis to procure multigram quantities of D-allo-threonine by utilizing an intermediate in our proposed route to the target glycal 3.

Towards this end, L-threonine was readily converted to oxazolidine 8 (Scheme 3 ). Initially, we chose to carry out a control experiment to test the feasibility of the approach outlined in Scheme 2. Oxazolidine 8 was treated with LDA at $-78{ }^{\circ} \mathrm{C}$ followed by exposure to MeI. The purpose of using MeI in this control experiment was twofold. While serving to confirm the facial selectivity of the alkylation (and ultimately, the protonation), this experiment would also allow us to unambiguously confirm if enolization was achieved.9 Surprisingly, after oxazolidine 8 was treated with LDA at $-78^{\circ} \mathrm{C}$ followed by MeI the starting material was recovered unchanged.

Though we acknowledged the possibility that the enolate was too hindered to be alkylated with MeI, we considered this scenario to be unlikely.10 It seemed more probable that the enolate had not been formed. This observation can be rationalized by considering possible conformations of oxazolidine 8 (Figure 2). An important consideration to the following analysis is that the carbamate will possess double bond character. In conformer $\mathbf{I}$, the hydrogen $\alpha$ to the ester is placed in plane with the carbamate in order to minimize allylic strain. This forces the ester into a pseudo-axial position and introduces an unfavorable synpentane interaction between the ester and the methyl substituent cis to the ester. An alternative conformer (II) is one in which the ester is placed in a pseudo-equatorial position, thereby alleviating the syn-pentane interaction. However, in order to minimize unfavorable steric interactions with the carbamate, the ester rotates about the $\mathrm{C}-\mathrm{C}$ bond (shown in red). As a consequence of this bond rotation, the $\alpha$-hydrogen is no longer stereoelectronically aligned for deprotonation.

This conformational analysis indicates that enolization will only take place if conformer I could be accessed. Using this analysis as a guide we sought to redesign the substrate such that the syn-pentane interaction would be alleviated. We rationalized this would be done most effectively by replacing the methyl group cis to the methyl ester with a proton.

Towards that end, methyl ester 9 was treated with pivaldehyde under acidic conditions to afford oxazolidine 10 (Scheme 4). With the syn-pentane interaction now removed, we were pleased to discover that exposure of $\mathbf{1 0}$ to LDA followed by a reverse quench with AcOH/ $\mathrm{MeOH}$ afforded the fully epimerized product in quantitative yield.11 This result strongly supports the assertion that enolization was precluded because of unfavorable non-covalent interactions described in Figure 2. 
After the successful epimerization12 of $\mathbf{1 0}$, oxazolidine $\mathbf{1 1}$ was converted to a Weinreb amide followed by treatment with ethynyl Grignard (Scheme 5). The ynone 12 was reduced to the corresponding propargyl alcohol with $\mathrm{NaBH}_{4} .13$ The resulting carbinol was protected as a TIPS ether and the oxazolidine was cleaved under acidic conditions. The resulting alkynol underwent cycloisomerization 14 in the presence of Wilkinson's catalyst to provide glycal 3 in $76 \%$ yield. 15

In conclusion, we have developed an efficient synthesis of the $\mathrm{N}$-(tert-butyloxycarbonyl)- $\mathrm{O}$ triisopropylsilyl-D-pyrrolosamine glycal of lomaiviticin A (1) and lomaiviticin B (2). Our synthesis is highlighted by the epimerization of the L-threonine derived oxazolidine $\mathbf{1 0}$ to oxazolidine 11, which possesses the desired relative configuration. This epimerization reaction was made possible only after control experiments indicated substituted oxazolidines may adopt conformations that preclude enolization. Glycal $\mathbf{3}$ will ultimately be converted to a suitable glycosyl donor for the glycosylation of the aglycones of $\mathbf{1}$ and $\mathbf{2}$. These results will be reported in due course.

\section{Acknowledgments}

Financial support for this project was provided by the NIH (CA125240), Merck Research Laboratories, Novartis, and AstraZeneca.

\section{References}

1. He H, Ding W-D, Bernan VS, Richardson AD, Ireland CM, Greenstein M, Ellestad GA, Carter GT. J. Am. Chem. Soc. 2001; 123:5362-5363. [PubMed: 11457405]

2. a) Gould SJ, Tamayo N, Melville CR, Cone MC. J. Am. Chem. Soc. 1994; 116:2207-2208. b) Mithani S, Weeratunga G, Taylor NJ, Dmitrienko GI. J. Am. Chem. Soc. 1994; 116:2209-2210. c) Marco-Contrelles J, Molina MT. Curr. Org. Chem. 2003; 7:1433-1442.

3. a) Nicolaou KC, Denton RM, Lenzen A, Edmonds DJ, Li A, Milburn RR, Harrison ST. Angew. Chem., Int. Ed. 2006; 45:2076-2081. b) Zhang W, Baranczak A, Sulikowski GA. Org. Lett. 2008; 10:1939-1941. [PubMed: 18410121] c) Nicolaou KC, Nold AN, Li H. Angew. Chem., Int. Ed. 2009; 48:5860-5862.

4. Krygowski ES, Murphy-Benenato K, Shair MD. Angew. Chem., Int. Ed. 2008; 47:1680-1684.

5. Moris WJ, Shair MD. Org. Lett. 2008; 11:9-12.

6. Gholap SL, Woo CM, Ravikumar PC, Herzon SB. Org. Lett. 2009; 11:4322-4325. [PubMed: 19719089]

7. Recently, the production of D-allo-threonine has been discontinued by Sigma-Aldrich.

8. a) Evans DA, Sjogren EB, Weber AE, Conn RE. Tetrahedron Lett. 1987; 28:39-42. b) Genet JP, Juge S, Mallart S. Tetrahedron Lett. 1988; 29:6765-6768. c) Pons D, Savignac M, Genet JP. Tetrahedron Lett. 1990; 31:5023-5026. d) Beaulieu PL. Tetrahedron Lett. 1991; 32:1031-1034. e) Blaskovich MA, Lajoie GA. Tetrahedron Lett. 1993; 34:3837-3840. f) Fischer PM, Sandosham J. Tetrahedron Lett. 1995; 36:5409-5412. g) Shao H, Goodman M. J. Org. Chem. 1996; 61:25822583. [PubMed: 11667077] h) Lloyd-Williams P, Sanchez A, Carulla N, Ochoa T, Giralt E. Tetrahedron. 1997; 53:3369-3382. i) Albanese D, Landini D, Lupi V, Penso M. Eur. J. Org. Chem. 2000:1443-1449.

9. The product resulting from protonation of the enolate from the $r$-face would be identical to the starting material. Therefore, we would not be able to unambiguously determine whether this product was a result of $r e$-face protonation or failure to achieve enolate formation.

10. Similar serine-derived oxazolidines have been alkylated with MeI: Brunner M, Saarenketo P, Straub T, Rissanen K, Koskinen AMP. Eur. J. Org. Chem. 2004:3879-3883.

11. The resulting oxazolidine 11 was cleaved under acidic conditions. The ${ }^{1} \mathrm{H}$ NMR of the resulting $\beta$ hydroxy- $\alpha$-amino ester matched the known ${ }^{1} \mathrm{H}$ NMR of the of $N$-Boc-L-allo-threonine methyl ester: 


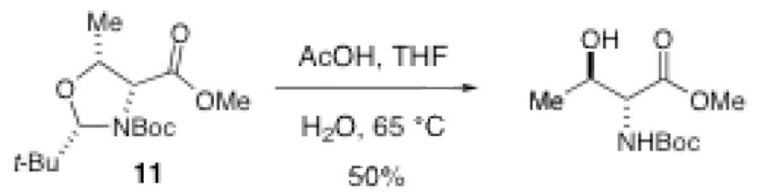

Ishizuka T, Kunieda T. Tetrahedron Lett. 1987; 28:4185-4188.

12. Experimental Procedure for epimerization of oxazolidine 10: To a solution of diisopropylamine (20 $\mathrm{ml}, 143 \mathrm{mmol})$ in THF $(252 \mathrm{ml})$ at $-78{ }^{\circ} \mathrm{C}$ was added $n \operatorname{BuLi}(53 \mathrm{ml}, 126 \mathrm{mmol})$ dropwise. The resulting LDA solution was allowed to stir at $-78{ }^{\circ} \mathrm{C}$ for 10 minutes. A solution of oxazolidine 10 $(15.5 \mathrm{~g}, 57.2 \mathrm{mmol})$ in THF $(114 \mathrm{ml})$ was added to the cooled solution $\left(-78^{\circ} \mathrm{C}\right)$ of LDA dropwise over 20 minutes. The resulting pale yellow solution was allowed to stir at $-78^{\circ} \mathrm{C}$ for 2 hours. The enolate solution was transferred to a rapidly stirring mixture of $\mathrm{AcOH}(78 \mathrm{ml})$ in $\mathrm{MeOH}(200 \mathrm{ml})$ at $-78^{\circ} \mathrm{C}$ and allowed to stir for 5 minutes. The reaction mixture was diluted with EtOAc (200 $\mathrm{ml})$, washed with saturated $\mathrm{NaHCO}_{3}(3 \times 100 \mathrm{ml})$, and brine. The organic layer was dried over $\mathrm{Na}_{2} \mathrm{SO}_{4}$, filtered, and concentrated to afford oxazolidine 11 (15.5 g, quantitative). Characterization data for 11: ${ }^{1} \mathrm{H}$ NMR $\left(600 \mathrm{MHz}, \mathrm{CDCl}_{3}\right) \delta 4.94(\mathrm{~s}, 1 \mathrm{H}), 4.57-4.55(\mathrm{~d}, J=7.1 \mathrm{~Hz}, 1 \mathrm{H}), 4.28-4.24$ (ddd, $J=6.5,7.1,12.7 \mathrm{~Hz}, 1 \mathrm{H}), 3.76(\mathrm{~s}, 3 \mathrm{H}), 1.49(\mathrm{~s}, 9 \mathrm{H}), 1.35-1.34(\mathrm{~d}, J=6.5 \mathrm{~Hz}, 3 \mathrm{H}), 1.04$ (s, 9H); ${ }^{13} \mathrm{C} \mathrm{NMR}\left(125 \mathrm{MHz}, \mathrm{CDCl}_{3}\right) \delta 170.4,155.5,96.9,74.3,64.1,51.8,36.8,28.4,26.5,26.3$, 16.0. HRMS (ESI) Mass calculated for $\mathrm{C}_{15} \mathrm{H}_{27} \mathrm{NO}_{5}[\mathrm{M}+\mathrm{Na}]^{+}, 324.1781$. Found 324.1793.

13. The streochemistry of the $\mathrm{NaBH}_{4}$ reduction was confirmed by treating the resulting propargyl alcohol with TFA in $\mathrm{CH}_{2} \mathrm{Cl}_{2}$ :

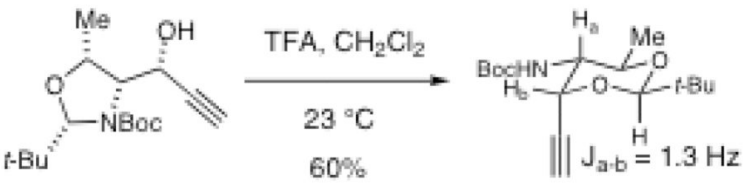

Villard R, Fotiadu F, Buono G. Tetrahedron: Asymmetry. 1998; 9:607-611.

14. Trost BM, Rhee YH. J. Am. Chem. Soc. 2003; 125:7482-7483. [PubMed: 12812465]

15. Characterization data for 3: ${ }^{1} \mathrm{H}$ NMR $\left(600 \mathrm{MHz}, \mathrm{CDCl}_{3}\right) \delta 6.35-6.34(\mathrm{~d}, J=6.3 \mathrm{~Hz}, 1 \mathrm{H})$, 4.84-4.83 (m, 1H), 4.67-4.65 (m, 1H), 4.20-4.18 (ddd, J = 3.4, 9.7, 11.6 Hz 1H), 4.17-4.16 (br s, $1 \mathrm{H}), 3.70(\mathrm{~m}, 1 \mathrm{H}), 1.47(\mathrm{~s}, 9 \mathrm{H}), 1.46-1.45(\mathrm{~d}, \mathrm{~J}=6.4 \mathrm{~Hz}, 3 \mathrm{H}), 1.14-1.13(\mathrm{~m}, 3 \mathrm{H}), 1.10-1.09(\mathrm{~d}, J=$ $6.3 \mathrm{~Hz}, 18 \mathrm{H}) ;{ }^{13} \mathrm{C} \mathrm{NMR}\left(125 \mathrm{MHz}, \mathrm{CDCl}_{3}\right) \delta 155.1,143.3,103.0,79.6,74.0,66.1,55.5,28.5$, 18.2, 17.9, 12.5. HRMS (ESI) Mass calculated for $\mathrm{C}_{20} \mathrm{H}_{39} \mathrm{NO}_{4} \mathrm{Si}[\mathrm{M}+\mathrm{Na}]^{+}, 408.2540$. Found 408.2533 . 

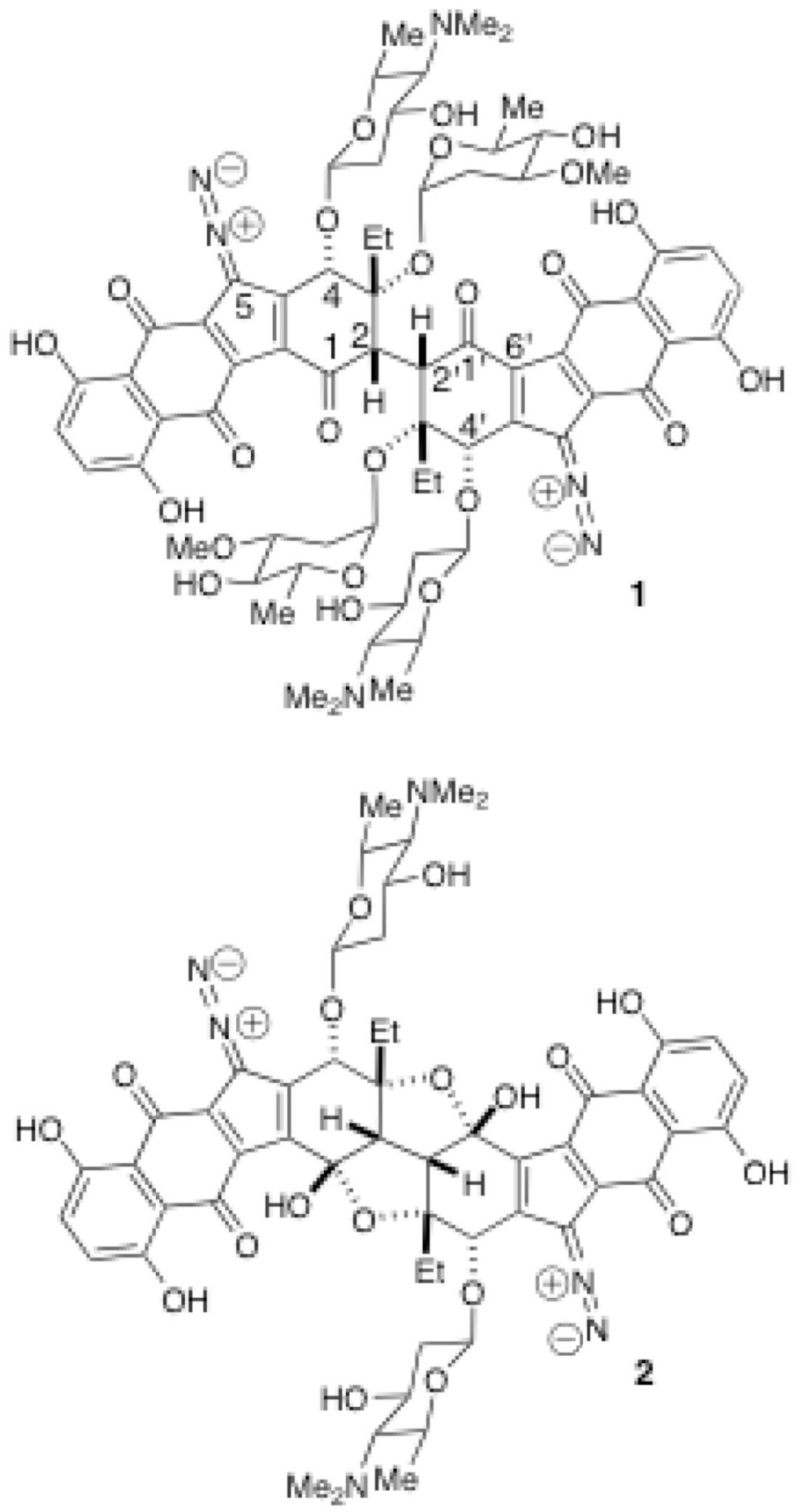

Figure 1.

Lomaiviticin A (1) \& Lomaiviticin B (2) 


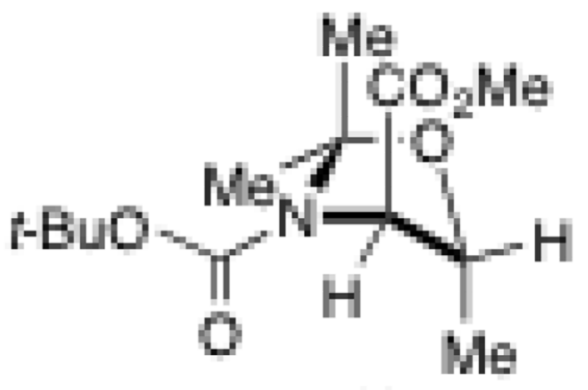

(I)

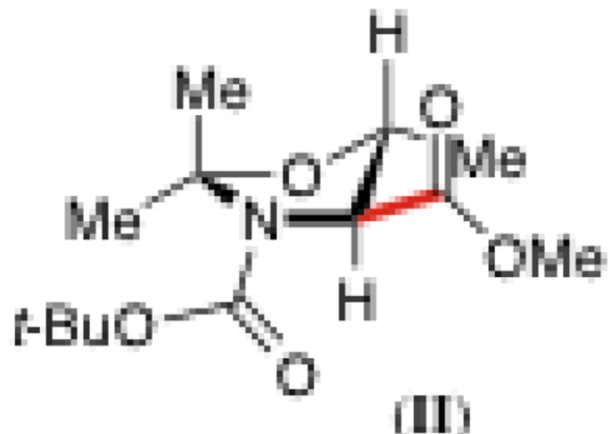

Figure 2.

Conformational Analysis of Oxazolidine 8 


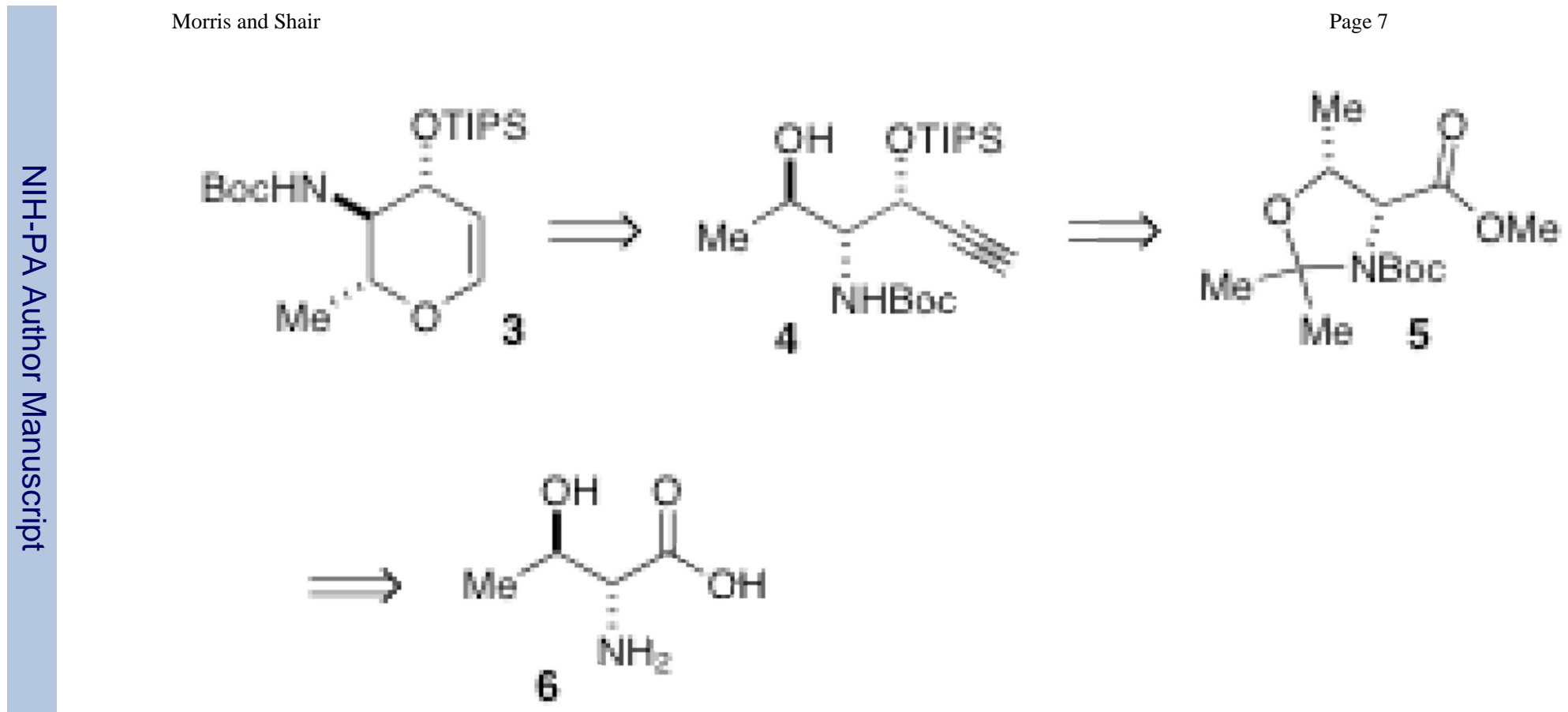

Scheme 1.

Retrosynthetic Analysis 


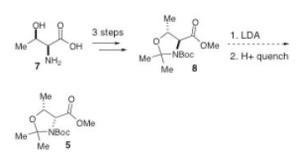

Scheme 2.

Proposed Epimerization of L-threonine 
<smiles>NC(C(=O)O)C([14NH])O</smiles>

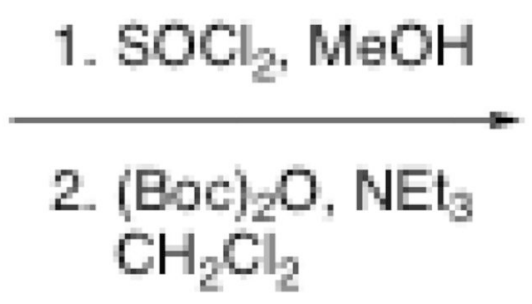<smiles>COC(=O)C([AlH2])C([14CH3])O</smiles>
96\%, 2 steps
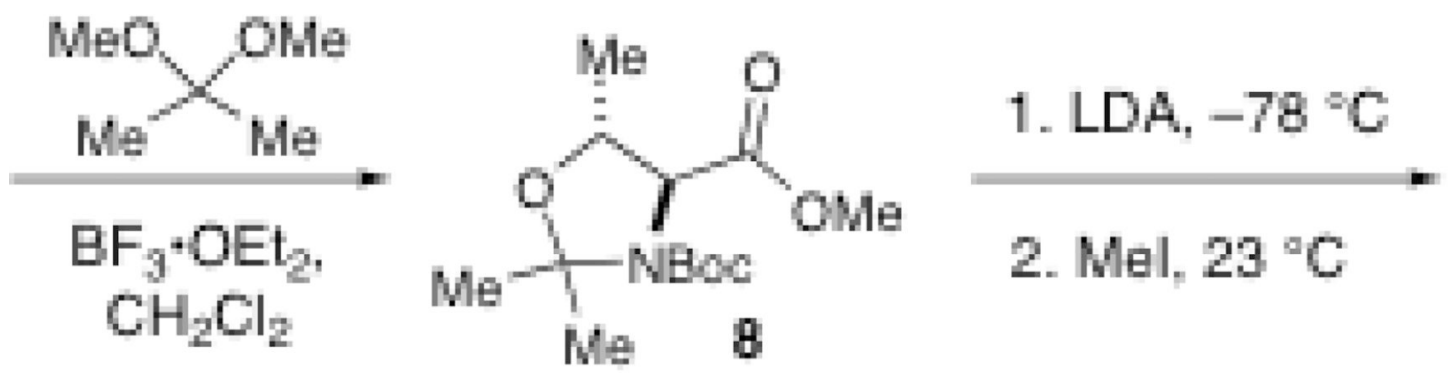

ang

Scheme 3.

Synthesis of Epimerization Precursor 


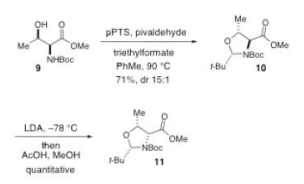

Scheme 4.

Synthesis of Revised Epimerization Substrate 
<smiles>COC(=O)C1[Nb]C([18F])OC1[13CH3]</smiles>

1. MeNH(ONe)-HCI FPrMgCl, THF, 20 C

2. Ethynyl Grignard, THF, $0^{\circ} \mathrm{C}$ to $23^{\circ} \mathrm{C}$

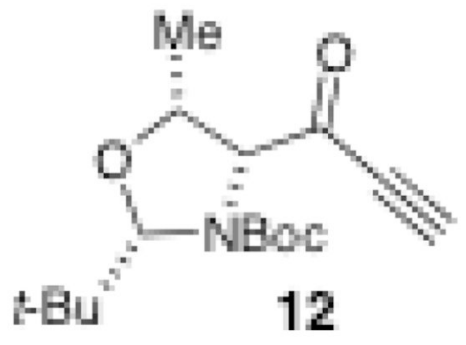
6gor, 2 steps

1. $\mathrm{NaBH}_{4}, \mathrm{MeOH}_{0} 0^{\circ} \mathrm{C}$

2. TIPSOTf, $\mathrm{CH}_{2} \mathrm{Cl}_{2}$ $0 \mathrm{E}$ 98\%, 2 steps dr $4: 1$
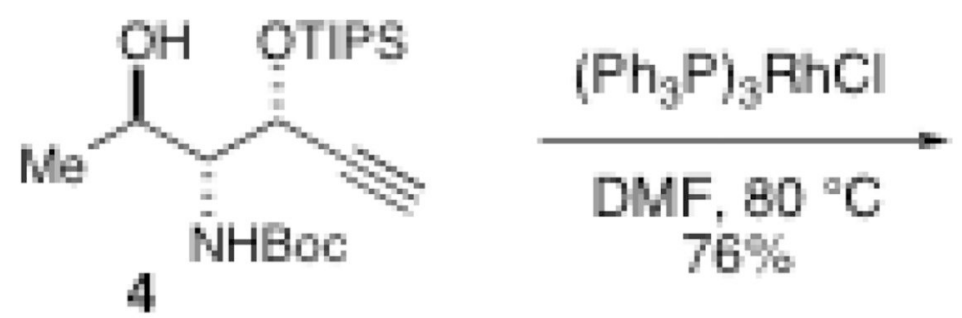

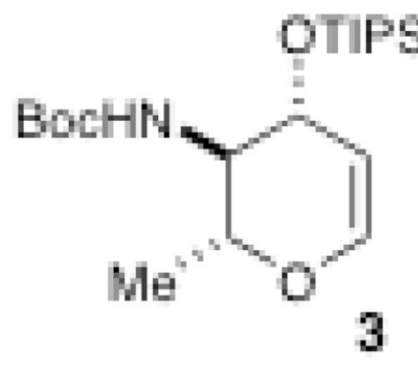

Scheme 5.

Synthesis of Glycal 3 